\title{
The Dual Amylin and Calcitonin Receptor Agonist, KBP-066, Induces an Equally Potent Weight Loss Across a Broad Dose Range While Higher Doses May Further Improve Insulin Action
}

\author{
Nina Sonne, Anna Thorsø Larsen, Kim Vietz Andreassen, Morten Asser Karsdal, \\ and Kim Henriksen
}

Nordic Bioscience Biomarkers and Research, Department of Endocrinology, Herlev, Denmark

Received November 6, 2019; accepted January 21, 2020

\begin{abstract}
Pharmacological treatment with dual amylin and calcitonin receptor agonists (DACRAs) cause significant weight loss and improvement of glucose homeostasis. In this study, the maximally efficacious dose of the novel DACRA, KeyBiosciencePeptide (KBP)-066, was investigated. Two different rat models were used: high-fat diet (HFD)-fed male Sprague-Dawley rats and male Zucker diabetic fatty (ZDF, fa/fa) rats to determine the maximum weight loss and glucose homeostatic effect, respectively. One acute study and one chronic study was performed in HFD rats. Two chronic studies were performed in ZDF rats: a preventive and an interventive. All studies covered a dose range of 5,50 , and $500 \mu \mathrm{g} / \mathrm{kg} \mathrm{KBP-066} \mathrm{delivered} \mathrm{by} \mathrm{sub-}$ cutaneous injection. Treatment with KBP-066 resulted in a significant weight reduction of $13 \%-16 \%$ and improved glucose tolerance in HFD rats, which was independent of dose concentration. Dosing with 50 and $500 \mu \mathrm{g} / \mathrm{kg}$ led to a transient but significant increase in blood glucose, both in the acute and the
\end{abstract}

chronic study in HFD rats. All doses of KBP-066 significantly improved glucose homeostasis in ZDF rats, both in the preventive and interventive study. Moreover, dosing with 50 and $500 \mu \mathrm{g} / \mathrm{kg}$ preserved insulin secretion to a greater extent than $5 \mu \mathrm{g} / \mathrm{kg}$ when compared with ZDF vehicle rats. Taken together, these results show that maximum weight loss is achieved with $5 \mu \mathrm{g} / \mathrm{kg}$, which is within the range of previously reported DACRA dosing, whereas increasing dosing concentration to 50 and $500 \mu \mathrm{g} / \mathrm{kg}$ may further improve preservation of insulin secretion compared with $5 \mu \mathrm{g} / \mathrm{kg}$ in diabetic ZDF rats.

\section{SIGNIFICANCE STATEMENT}

Here we show that KeyBiosciencePeptide (KBP)-066 induces an equally potent body weight loss across a broad dose range in obese rats. However, higher dosing of KBP-066 may improve insulin action in diabetic rats both as preventive and interventive treatment.

\section{Introduction}

The number of patients with obesity is increasing worldwide and in its wake follows comorbidities such as type 2 diabetes, nonalcoholic fatty liver disease, cardiovascular diseases, and an overall increased morbidity (Younossi et al., 2016; Bentham et al., 2017; Zheng et al., 2018). A successful antiobesity drug must therefore target not only obesity but also insulin resistance and/or other parameters. It is in this setting that amylin therapy has become relevant as the peptide helps controlling postprandial glucose fluctuations (Kolterman et al., 1995; Edelman and Weyer, 2002; Fineman et al., 2002) and demonstrate satiation properties (Lutz et al., 1995; Chapman et al., 2005; Lutz, 2005). The stable amylin analog, Pramlintide, has clinically been shown to induce a modest but significant weight loss of up to $3.6 \mathrm{~kg}$ (placebo-corrected)

Conflict of interest. M.A.K. and K.H. own stock in Nordic Bioscience. M.A.K., K.V.A. and K.H. hold patent in KBP-066. All other authors disclose no conflict of interest.

https://doi.org/10.1124/jpet.119.263723. in obese subjects (Aronne et al., 2007). In addition to that, Pramlintide improves HbA1c and postprandial glucose control while causing a relative reduction in daily insulin use (Ratner et al., 2002; Hollander et al., 2003, 2004). Despite great potential, current amylin therapy (combined with insulin) lacks clinical efficacy in the treatment of type 2 diabetes and particularly obesity.

Dual amylin and calcitonin receptor agonists (DACRAs) are a class of peptides, which distinguish themselves from amylin agonists because they activate both the amylin receptor and the calcitonin receptor in a prolonged fashion (Andreassen et al., 2014b; Gydesen et al., 2016). DACRA treatment is known to reduce body weight, suppress food intake and glucagon release, slow gastric emptying, improve glucose tolerance and preserve $\beta$-islets, and possibly increase energy expenditure in a preclinical setting (Hjuler et al., 2016, 2017; Gydesen et al., 2017b). These beneficial effects, in addition to being superior to amylin and amylin analogs in vitro (Gydesen et al., 2016) and in vivo (Larsen et al., 2019), make DACRAs candidates for future antiobesity and antidiabetic drugs.

ABBREVIATIONS: AT, adipose tissue; BG, blood glucose; CTRa, calcitonin receptor (subtype a); DACRA, dual amylin and calcitonin receptor agonist; HFD, high-fat diet; iAUC, incremental area under the curve; KBP, KeyBiosciencePeptide; OGTT, oral glucose tolerance test; tAUC, total area under the curve; ZDF, Zucker diabetic fatty. 
TABLE 1

Amino acid sequence of human calcitonin, salmon calcitonin, KBP-066, and rat amylin

KBP-066 consists of an NH2-terminal acetyl group (Ac), an COOH-terminal amide group, and a 2-aminoisobutyric acid modification symbolized by the letter $\mathrm{X}$.

\begin{tabular}{lclc}
\hline Name & N-terminal & & C-terminal \\
\hline Salmon calcitonin: & & CSNLSTCVLGKLSQELHKLQTYPRTNTGSGTP & - NH2 \\
Human calcitonin: & & CGNLSTCMLGTYTQDFNKFHTFPQTAIGVGAP & - NH2 \\
KBP-066: & Ac- & CSNLSTCXLGRLSQDLHRLQTYPKTDVGANAP & - NH2 \\
Rat amylin: & & KCNTATCATQRLANFLVRSSNNLGPVLPPTNVGSNTY & -NH2 \\
\hline
\end{tabular}

To date, the highest dose of a KeyBiosciencePeptide (KBP) DACRA tested in a chronic study is $40 \mu \mathrm{g} / \mathrm{kg}$, although a single dosing of $50 \mu \mathrm{g} / \mathrm{kg}$ has been tested (Hjuler et al., 2016; Gydesen et al., 2017a). Chronically, dose-escalated 10 and $40 \mu \mathrm{g} / \mathrm{kg}$ of KBP-042 and KBP-089 do not differ from the more commonly used doses of $2.5-5 \mu \mathrm{g} / \mathrm{kg}$ in terms of body weight, accumulated food intake, gastric emptying, and glucose tolerance (Hjuler et al., 2016; Gydesen et al., 2017a). In single-injection studies, 40 and $50 \mu \mathrm{g} / \mathrm{kg}$ of KBP-089 and KBP-042 suppress food intake to a greater extent than $5 \mu \mathrm{g} / \mathrm{kg}$, namely up to 72 hours postinjection (Hjuler et al., 2016; Gydesen et al., 2017a). However, subcutaneous doses above $5 \mu \mathrm{g} / \mathrm{kg}$ of a KBP have not been tested in diabetic models (Andreassen et al., 2014a). Previous studies have shown that a combination of a DACRA and metformin or a glucagon-like peptide- 1 analog caused larger effects than either treatment alone (Gydesen et al., 2017a; Hjuler et al., 2017). This could indicate that the maximum effect of the DACRAs has not been reached, particularly in the diabetic system.

In this study, we set out to investigate whether the current standard dose of $2.5-5 \mu \mathrm{g} / \mathrm{kg}$ DACRA is indeed the maximally efficacious dose. For that purpose, we used the DACRA, KBP-066, at doses of 5, 50, and $500 \mu \mathrm{g} / \mathrm{kg}$. A dose-escalation study in high-fat diet (HFD)-fed rats was conducted to investigate the weight-lowering effect using a more progressive dose-escalation regimen and a higher maximum dose than previously tested. Furthermore, we investigated the glucose regulatory effects of KBP-066 in Zucker diabetic fatty (ZDF) $(f a / f a)$ rats using the same dose range, both as prevention therapy and intervention therapy.

\section{Methods}

Peptide Therapy. Synthetic KBP-066 (Synpeptide, Shanghai, China) was dissolved in sterile saline $(0.9 \%)$ for subcutaneous injections. Aliquots were kept at $-20^{\circ} \mathrm{C}$ and thawed immediately before use. The standard dose of KBP-066 was based on previous comparable DACRAs studies (Gydesen et al., 2016, 2017a,b; Hjuler et al., 2016). Amino acid sequence of KBP-066 is shown in Table 1, and receptor binding and activity is shown in Fig. 1.

In Vitro Receptor Binding and Activity. The binding potency of KBP-066 was confirmed in cell lines with heterologous overexpression of the calcitonin receptor (subtype a) (CTRa) or the amylin receptor $(\mathrm{CTRa}+$ receptor activity modifying protein 3$)$ by evaluation of $\beta$-arrestin recruitment. The $\beta$-arrestin assay was performed as described in Gydesen et al. (2017a). Data analysis was performed as described in Andreassen et al. (2014a).

Animal Experiments. All animal procedures were performed in accordance with the guidelines from the Animal Welfare Division of the Danish Ministry of Justice under the institutional license issued to Nordic Bioscience (2016-15-0201-00910). The rats were kept under a 12-hour light/ dark cycle, with a controlled temperature and relative humidity $\left(21-23^{\circ} \mathrm{C}\right.$ and 55\%-65\%). Male Sprague-Dawley rats (Envigo, Netherlands) were housed two per cage and male ZDF rats (strain code: 370, falfa) (Charles River, Lyon, France) were housed two to three per cage in the prevention study and three per cage in the intervention study. The standard type IV cages contained standard wood chips enriched with nesting material, wood sticks, and red-tinted huts. The rats had ad libitum access to food and tap water. Dosing was performed once daily during the light cycle (noon, \pm 1 hour) via subcutaneous injection based on nonfasting body weight.

Acute Dosing in High-Fat Diet-Fed Male Sprague-Dawley Rats. Sixteen male Sprague-Dawley rats arrived in the facility at 12 weeks of age and were fed a 60\% kcal fat diet (\#D12492; Research Diets Inc., NJ) for 4 weeks prior to the study. Two identical studies were conducted and pooled. The rats were assigned to groups based on body weight: vehicle (saline) or KBP-066 (5, 50, or $500 \mu \mathrm{g} / \mathrm{kg})(n=4$ per group per experiment, avg. body weight first run; $413 \mathrm{~g} \pm 14$ S.D.). After a 5-hour fast, the rats received one dose of either: saline, 5, 50, or $500 \mu \mathrm{g} / \mathrm{kg}$ KBP-066 by subcutaneous injection. Blood glucose (BG) was monitored every 30th minute for 2 hours, during which the rats were deprived of food. Body weight and food intake were monitored daily for the following 8 days. The experiment was repeated after a 2-week wash-out period (avg. body weight second run $=436 \mathrm{~g} \pm 17$ S.D.).

High-Dose Escalation in High-Fat Diet-Fed Male Sprague-Dawley Rats. 40 male Sprague-Dawley rats were obtained at 5 to 6 weeks of age and fed a $60 \%$ kcal fat diet (\#D12492; Research Diets Inc.) for 13 weeks before being assigned to treatment groups: vehicle (saline) or KBP-066 $(5,50$, or $500 \mu \mathrm{g} / \mathrm{kg}$ ), based on body weight (avg.: $489 \mathrm{~g} \pm 29$ S.D.). Vehicle animals $(n=10)$ received saline
A

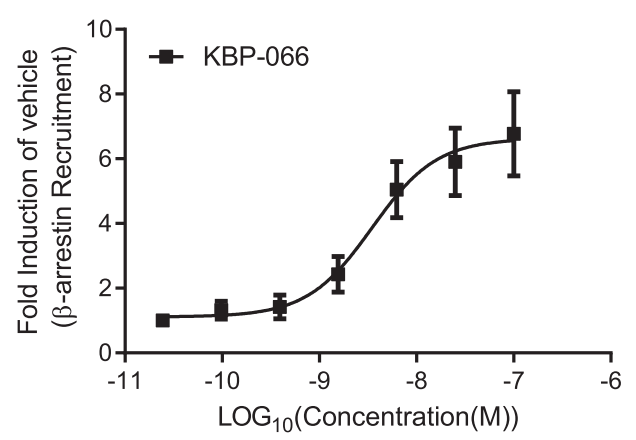

B

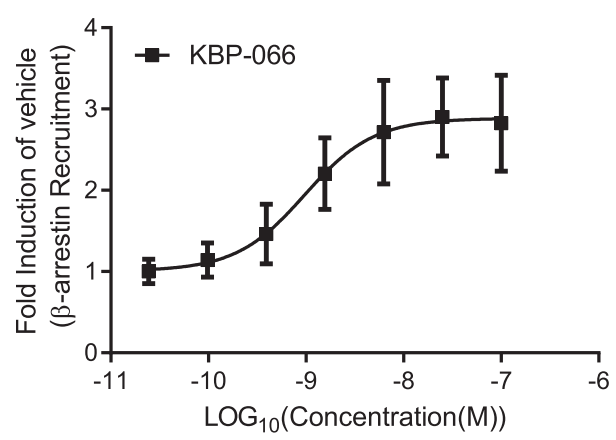

Fig. 1. Dose-response curves of KBP-066 in a cell-based $\beta$-arrestin recruitment assay. $\beta$-Arrestin induction in a calcitonin receptor expressing cell line (CTRa) (A) and in an amylin receptor (CTRa + RAMP3) (B) expressing cell line. Three individual runs are pooled with four technical replicates per run, $n=12$ in total per concentration. All data are \pm S.D. RAMP3, receptor activity modifying protein 3. 
while 30 rats initiated a four-step dose-escalation regimen of KBP-066 (5, 50, or $500 \mu \mathrm{g} / \mathrm{kg}$ KBP-066, $n=10$ per group). Saline and KBP-066 were delivered by subcutaneous injection. At study start, all treatment groups received $2.5 \mu \mathrm{g} / \mathrm{kg} \mathrm{KBP}-066$; on day 7 , all groups escalated to $5 \mu \mathrm{g} / \mathrm{kg}$; on day 14 , two groups escalated to $50 \mu \mathrm{g} / \mathrm{kg}$; on day 21 , one group finally escalated to $500 \mu \mathrm{g} / \mathrm{kg}$. Food intake and body weight were recorded daily throughout the first 5 weeks, then once weekly. 24-hour food intake and feces output were measured and collected after 5 and 12 weeks. The feces was stored at $-80^{\circ} \mathrm{C}$ followed by sample processing and bomb calorimetry analysis. Oral glucose tolerance tests (OGTTs) were performed 6 and 11 weeks into the study ( 3 and 8 weeks after completion of dose escalation), with and without predosing of saline and KBP-066, respectively. At the end of the study (12 weeks from first dose), the rats were euthanized, and the liver, inguinal, epididymal, and perirenal adipose tissues (ATs) were surgically removed and weighed.

High-Dose Prevention Study in Male Zucker Diabetic Fatty Rats. 40 male ZDF rats ( $f a / f a$ ) arrived at 5 to 6 weeks of age and were fed a Purina FormuLab diet (\#5008; Brogaarden, Lynge, Denmark). The rats were acclimatized for 6 days before being assigned to groups based on fasting BG $\left(8.0 \mathrm{mmol} \cdot \mathrm{L}^{-1} \pm 0.7\right.$ S.D. $)$ and body weight $(157 \mathrm{~g}$ \pm 13 S.D.). Rats were assigned to either vehicle (saline, $n=10$ ) or $\mathrm{KBP}-066(5,50$, or $500 \mu \mathrm{g} / \mathrm{kg}, n=10$ per group). The ZDF rats did not undergo dose escalation. Saline and KBP-066 were delivered by subcutaneous injection.

The 9 -week study period included 6 -hour fasting BG every 2 to 3 weeks, two OGTTs 3 and 8 weeks into the study, and HbA1c at study end. Two rats died after the first OGTT, one vehicle and one $500 \mu \mathrm{g} / \mathrm{kg} \mathrm{KBP-066}$ likely due to dehydration. Consequently, all rats received subcutaneous saline after the second OGTT and no rats died. The body weight, food intake, and fasting BG data from the deceased rats are included.

High-Dose Intervention Study in Male Zucker Diabetic Fatty Rats: Pilot Study. Data from two almost identical studies were pooled. In each study, nine male ZDF ( $f a / f a$ ) rats arrived 5 to 6 weeks of age and were fed the Purina FormuLab diet. At 9 to 10 weeks of age, the rats were assigned to vehicle (saline, $n=6 /$ group after pooling) or KBP-066 treatment ( 5 or $500 \mu \mathrm{g} / \mathrm{kg}, n=6 /$ group after pooling) based on fasting BG (pooled baseline fasting BG: $18.9 \pm 6.1$ S.D., $22.7 \pm 9.2$ S.D., and $18.3 \pm 7.2$ S.D. $\mathrm{mmol} \cdot \mathrm{L}^{-1}$, respectively). Saline and KBP-066 were delivered by subcutaneous injection. Study 1 lasted for 45 days with once weekly 6 -hour-fasted BG at day 1 (baseline), 8, 15, 22, 29, 36 (including HbA1c measurement), and 43, followed by an OGTT without predosing on day 45 . Study 2 lasted for 43 days with once weekly 6 -hour-fasted BG at day 1 (baseline), 8, 15, $22,29,36$, and 41 (including HbA1c measurement), followed by an OGTT without predosing on day 43. Despite the different days of the endpoint fasting BG, HbA1c, and OGTTs, the two studies were still pooled. One rat in the $500 \mu \mathrm{g} / \mathrm{kg}$ group was terminated after the last fasting BG due to injury to the tail unrelated to the treatment. Thus, $n=5$ in the $500 \mu \mathrm{g} / \mathrm{kg}$ group during the OGTT. Body weight and food intake was monitored daily during the 1 st week and then once weekly.

Oral Glucose Tolerance Tests. 16-hour-fasted Sprague-Dawley rats received $2 \mathrm{~g}$ glucose/kg and 11-hour-fasted $\mathrm{ZDF}$ rats received $1 \mathrm{~g}$ glucose $/ \mathrm{kg}$, both by oral gavage. In experiments with predosing, drug or saline was administered at $t=-30$ and glucose challenge at $t=0$. Blood was collected from the tail vein before drug and glucose administration, and then $15,30,60,120$, and 180 minutes postglucose challenge. Only BG was measured at $t=180$ minutes. In experiments without predosing, the OGTT started at $t=-30$ in Sprague-Dawley rats and $t=0$ in ZDF rats but was otherwise identical as described above.

Biochemical Analysis. Blood was collected in EDTA tubes and centrifuged at $5000 \mathrm{rpm}$ for 10 minutes at $4^{\circ} \mathrm{C}$. Plasma EDTA was stored at $-20^{\circ} \mathrm{C}$ until insulin analysis (Mercodia rat insulin ELISA; Mercodia, Uppsala, Sweden) according to the manufacturer's instructions. Blood glucose was measured with Accu-Check Avia monitoring system (Roche Diagnostics, Rotkreuz, Switzerland).

HbA1c. HbA1c was measured from the tail vein and analyzed using the DCA Vantage Analyzer (Siemens, Erlangen, Germany).

Bomb Calorimetry. Feces collected from Sprague-Dawley rats was stored at $-80^{\circ} \mathrm{C}$ until sample processing by which the feces dried for 3 days at $60^{\circ} \mathrm{C}$ and then stored in air-tight containers. Dried feces ( $\sim 0.3 \mathrm{~g})$ and benzoic acid tablet ( $\sim 0.5 \mathrm{~g}$ ) (IKA, Staufen, Germany) were weighed for each sample, mixed, and the gross energy content (Joule per gram) was determined using the isoperibol mode of a bomb calorimeter (C6000; IKA) (Zhang et al., 2017). The measurements were done according to the international standard ISO 9831:1998 (E) without correction for heat formation of acids.

Statistical Analysis. All data are presented as means \pm S.E.M. unless otherwise specified. Statistical differences between groups was evaluated by one-way ANOVA followed by a post hoc test: either Tukey's or Kruskal-Wallis multiple comparisons test depending on the normality test outcome. In some cases, two-way ANOVA with repeated measures followed by Tukey's multiple comparison test was applied. A mixed-effects model was performed when two-way ANOVA was not possible due to missing values, followed by Tukey's multiple comparison test. All analyses were performed using GraphPad Prism 8 software (GraphPad Prism, San Diego, CA). A $P$ value of $<0.05$ was considered statistically significant shown with one symbol, a $P$ value of $<0.01$ is shown with two symbols, and a $P$ value of $<0.001$ is shown with three symbols.

\section{Results}

KBP-066 Potently Binds and Activates the Calcitonin and Amylin Receptor. The amino acid sequence of KBP066 is shown in Table 1 in comparison with the dual agonist salmon calcitonin, as well as human calcitonin and rat amylin.
A

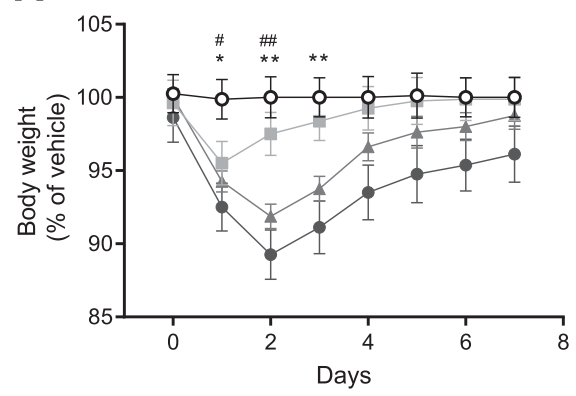

B

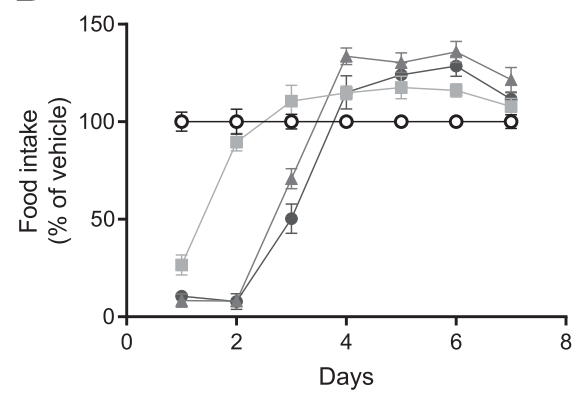

C

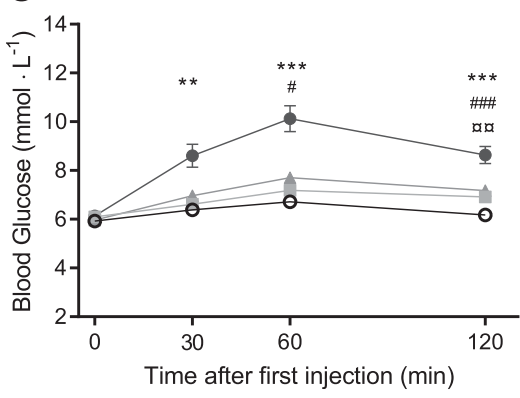

$500 \mu \mathrm{g} / \mathrm{kg}$

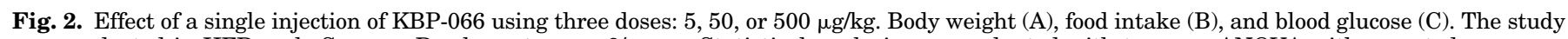

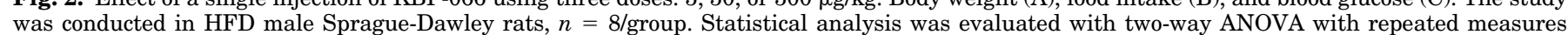
followed by Tukey's multiple comparisons test. ${ }^{*} 500 \mu \mathrm{g} / \mathrm{kg}$ vs. vehicle. ${ }^{\#} 50 \mu \mathrm{g} / \mathrm{kg}$ vs. vehicle. $a 5 \mu \mathrm{g} / \mathrm{kg}$ vs. vehicle. All data are \pm S.E.M. 
A

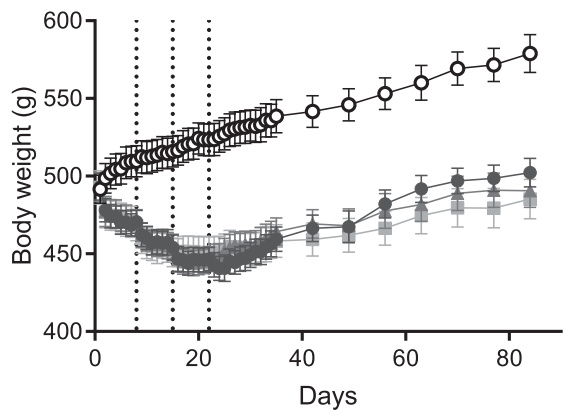

-o- Vehicle

C

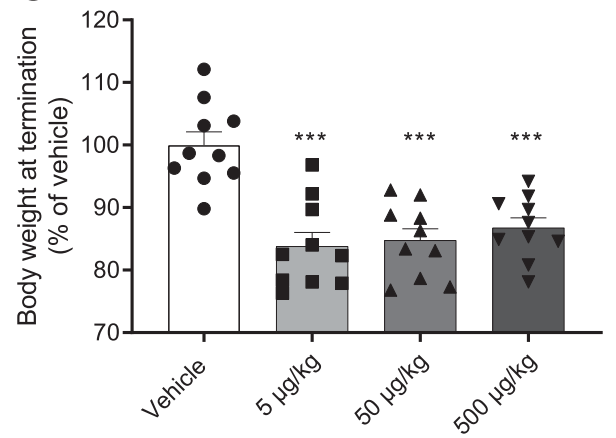

E

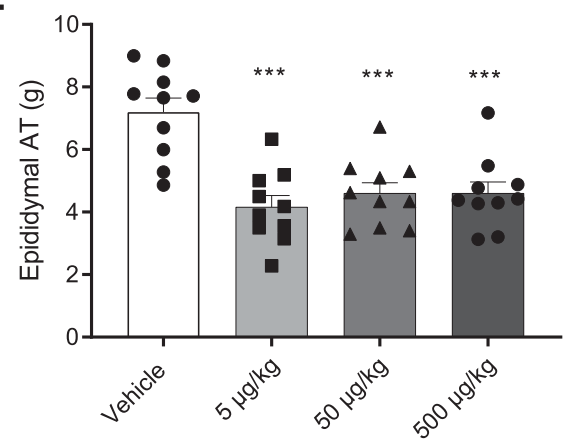

G

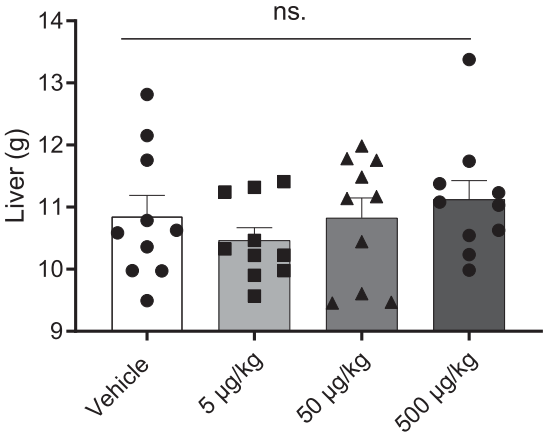

B
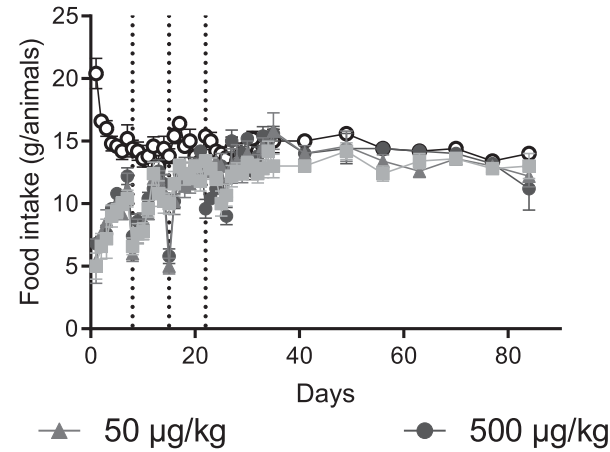

D

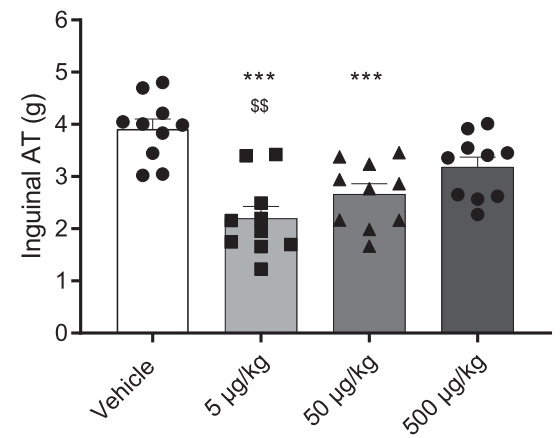

$\mathbf{F}$

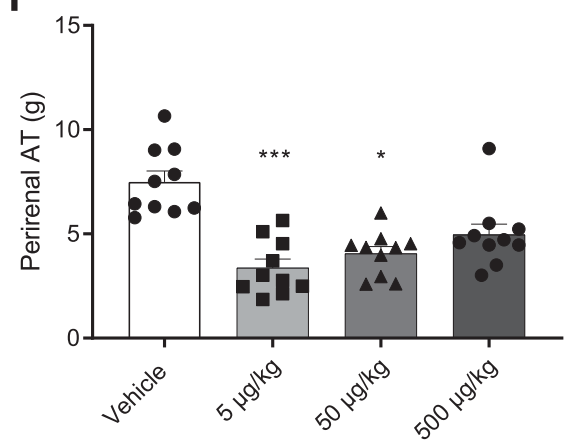

Fig. 3. Dose escalation from 2.5, 5, 50 and500 $\mu \mathrm{g} / \mathrm{kg} \mathrm{KBP}-066$ in HFD rats. Body weight (A) and food intake (B) (overnight fasted at study start). Dotted line illustrates dose escalation. Body weight at termination (C), weight of inguinal (D-G), epididymal and perirenal adipose tissue and liver at termination. $n=10$ /group. Statistical analysis between groups was evaluated by one-way ANOVA with Tukey's multiple comparisons test, all except (F and $\mathrm{G}$ ) that were evaluated with Kruskal-Wallis test: * compared with vehicle. ${ }^{\$} 5 \mu \mathrm{g} / \mathrm{kg}$ vs. $500 \mu \mathrm{g} / \mathrm{kg}$. All data are \pm S.E.M. ns, not significant.
Of note, the reactive amino acid methionine has been substituted with 2-aminoisobutyric acid to improve formulation.

KBP-066 potently activated the calcitonin and amylin receptor (Fig. 1) and was comparable to previously published DACRAs in vitro (Gydesen et al., 2016, 2017a) and in vivo (unpublished data).

$500 \mu \mathrm{g} / \mathrm{kg}$ KBP-066 Acutely Raises Blood Glucose in HFD Rats. To investigate the acute effect of KBP-066 on body weight, food intake, and BG, KBP-066 was administered in three doses: 5,50 , or $500 \mu \mathrm{g} / \mathrm{kg}$ in a single-injection study. The 50 and $500 \mu \mathrm{g} / \mathrm{kg}$ dose resulted in a significant weight reduction, whereas $5 \mu \mathrm{g} / \mathrm{kg}$ tended to reduce body weight (Fig. 2A). Likewise, food intake was suppressed for 1 day with the $5 \mu \mathrm{g} / \mathrm{kg}$ dose, whereas 50 and $500 \mu \mathrm{g} / \mathrm{kg}$ suppressed food intake for 3 days (Fig. 2B), thus reflecting the body weight loss. Dosing with $500 \mu \mathrm{g} / \mathrm{kg}$ significantly increased BG levels at $t=30-120$ minutes postinjection compared with all groups (Fig. 2C), whereas 5 and $50 \mu \mathrm{g} / \mathrm{kg}$ increased BG levels 
A

Pre-dosed OGTT

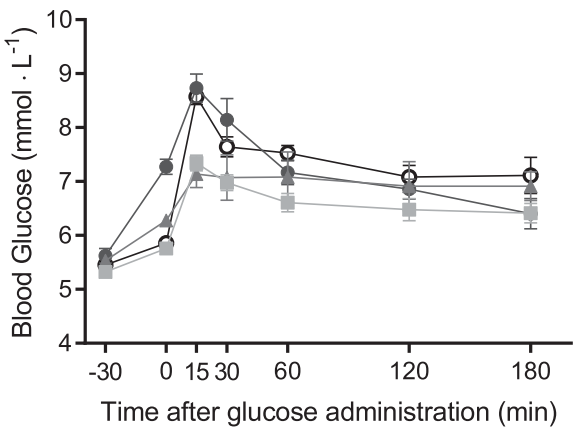

-o- Vehicle $-5 \mu \mathrm{g} / \mathrm{kg}$

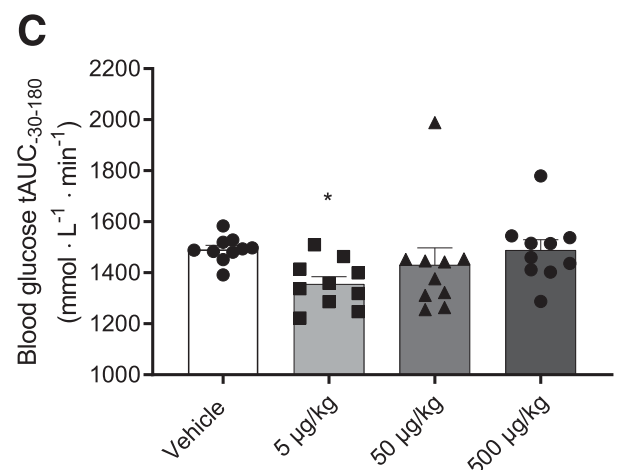

E

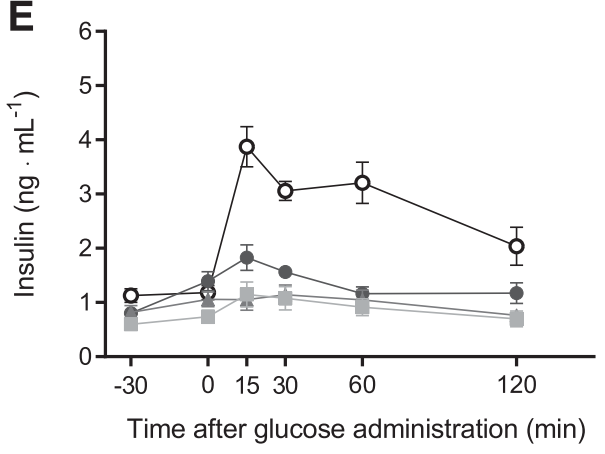

-o- Vehicle $-5 \mu \mathrm{g} / \mathrm{kg}$

G

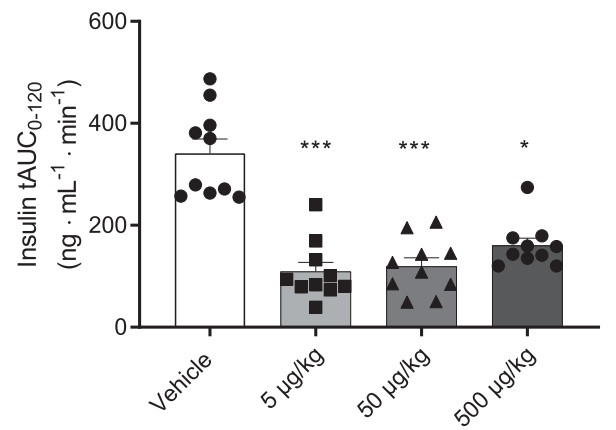

\section{B Non-pre-dosed OGTT}

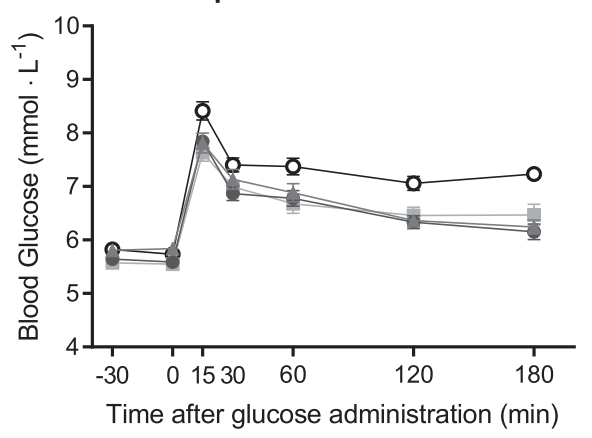

$\neg 50 \mu \mathrm{g} / \mathrm{kg} \longrightarrow 500 \mu \mathrm{g} / \mathrm{kg}$

D

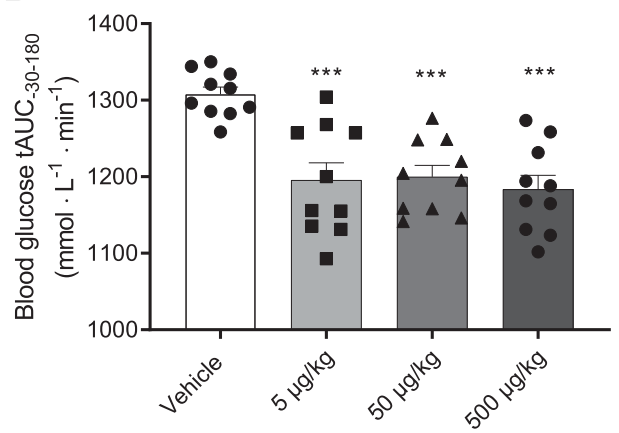

$\mathbf{F}$

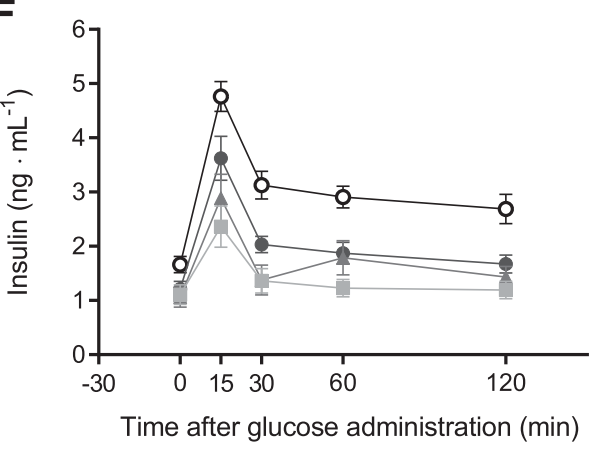

$\neg 50 \mu \mathrm{g} / \mathrm{kg} \rightarrow 500 \mu \mathrm{g} / \mathrm{kg}$

H

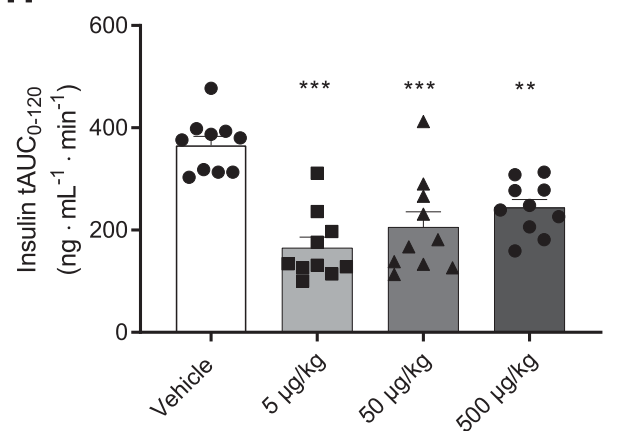

Fig. 4. OGTTs in HFD rats. (A, C, E, and G) The predosed OGTT was performed 6 weeks into the study and data are shown. (B, D, F, and $\mathrm{H}$ ) Eleven weeks into the study, non-predosed OGTT was performed. Blood glucose is shown (A and $\mathrm{B})$; tAUC of blood glucose is shown ( $\mathrm{C}$ and D). Insulin levels are shown ( $\mathrm{E}$ and $\mathrm{F}$ ), and tAUC of insulin is shown ( $\mathrm{G}$ and $\mathrm{H}$ ). $n=10$ /group. Predosing is performed at $t=-30$ minutes and glucose is administered at $t=0$ minutes. Statistical analysis of (A) was evaluated with two-way ANOVA with Tukey's multiple comparisons test, (C and $\mathrm{G}$ ) was evaluated with one-way ANOVA with Kruskal-Wallis multiple comparisons test, and (D and H) with Tukey's test. * compared with vehicle. All data are \pm S.E.M. compared with vehicle at $t=60$ and 120 minutes postinjection, respectively.

High-Dose Escalation with KBP-066 Does Not Result in Additional Weight Loss in HFD Rats. We tested 5, 50, and $500 \mu \mathrm{g} / \mathrm{kg}$ in a chronic dose-escalation study to determine the maximal weight-lowering effect of KBP-066. A progressive dosing regimen was initiated which consisted of four steps: $2.5,5,50$, and $500 \mu \mathrm{g} / \mathrm{kg}$.

As expected, KBP-066 treatment transiently reduced food intake at each dose-escalation step (Fig. 3B), which translated into a significant $13 \%-16 \% \pm 2 \%$ vehicle-corrected weight loss that was maintained throughout the study (Fig. 3, A and C), 
albeit independently of dose concentration. In line with the weight loss, 5 and $50 \mu \mathrm{g} / \mathrm{kg} \mathrm{KBP}-066$ resulted in significant weight reductions of all ATs (Fig. 3, D-F), whereas $500 \mu \mathrm{g} / \mathrm{kg}$ only caused a significant reduction in the epididymal AT (Fig. 3E). Treatment had no effect on liver weight (Fig. 3G).

The Acute Effects of $500 \mu \mathrm{g} / \mathrm{kg}$ KBP-066 on Blood Glucose Persist after 3 Weeks' Treatment in HFD Rats. The OGTTs had two purposes: 1) to investigate the dose range effect of KBP-066 on glucose tolerance after short(3 weeks after completion of dose escalation) and long-term (8 weeks after completion of dose escalation) treatment and 2) to examine glucose tolerance in the presence (with predosing 30 minutes prior to OGTT) or absence (no predosing) of potentially acute drug-induced effects.

Consistent with the acute dosing study and previous literature (Hjuler et al., 2016), predosing with 50 and $500 \mu \mathrm{g} / \mathrm{kg}$ resulted in an acute and significant increase in BG levels $(P<0.01$ and $<0.001)$ from $t=-30$ to $t=0$ minutes compared with vehicle (Fig. 4A). Only $5 \mu \mathrm{g} / \mathrm{kg}$ lowered BG levels significantly by tAUC (Fig. 4C). However, all treatment groups had a significantly lower insulin secretion (Fig. 4, E and $\mathrm{G}$ ) without compromising glucose control, which suggests an improved insulin sensitivity.

The second OGTT without predosing led to an almost identical course of BG levels in the treatment groups, all of which were significantly lower than the vehicle group by tAUC (Fig. 4, B and D). Likewise, KBP-066, regardless of concentration, significantly lowered the insulin secretion compared with vehicle, although $5 \mu \mathrm{g} / \mathrm{kg}$ tended to require the lowest insulin concentration to control BG levels (Fig. 4, F and H).

High-Dose KBP-066 Treatment Increases Fecal Energy Loss. Previous studies using pair-fed and pair-weighed groups matching KBP treatment groups have indicated that the weight loss cannot solely be explained by decreased food intake but perhaps that energy expenditure is altered (Gydesen et al., 2016, 2017b; Hjuler et al., 2016). However, the possible role of drug-induced changes in fecal energy loss has not been investigated. Thus, we investigated this by bomb calorimetry. After 5 weeks of treatment, fecal energy loss of 5 and $50 \mu \mathrm{g} / \mathrm{kg}$-treated rats trended higher $(P=0.07$ and $P=$ 0.05 ) than vehicle, whereas $500 \mu \mathrm{g} / \mathrm{kg}$ exhibited a significantly higher fecal energy loss (Fig. 5). At study end, both 50 and $500 \mu \mathrm{g} / \mathrm{kg}$ had a significantly higher fecal energy content compared with vehicle. However, there was no difference between vehicle and KBP-066 groups when food intake and total fecal output were taken into account.

KBP-066 Significantly Improves Fasting Blood Glucose and HbA1c in ZDF Rats Both as Preventive and Interventive Treatment. Two studies were performed in ZDF ( $f a / f a$ ) rats: a preventive and an interventive study. The aims of the two studies were to investigate and compare the glucose homeostatic effects of 5, 50, and $500 \mu \mathrm{g} / \mathrm{kg} \mathrm{KBP}-066$, with treatment initiated before and after onset of disease.

In both studies, KBP-066 treatment transiently suppressed food intake and body weight (Fig. 6, A-D). However, the body weight of KBP-066-treated rats exceeded that of vehicle during the studies without a concomitant increase in food intake, likely explained by a more well-controlled glucose homeostasis (Feigh et al., 2012; Andreassen et al., 2014a; Hjuler et al., 2017) (Fig. 6, E-H). Specifically, KBP-066 significantly improved fasting BG throughout the prevention study regardless of dosing concentration. Likewise, intervention therapy

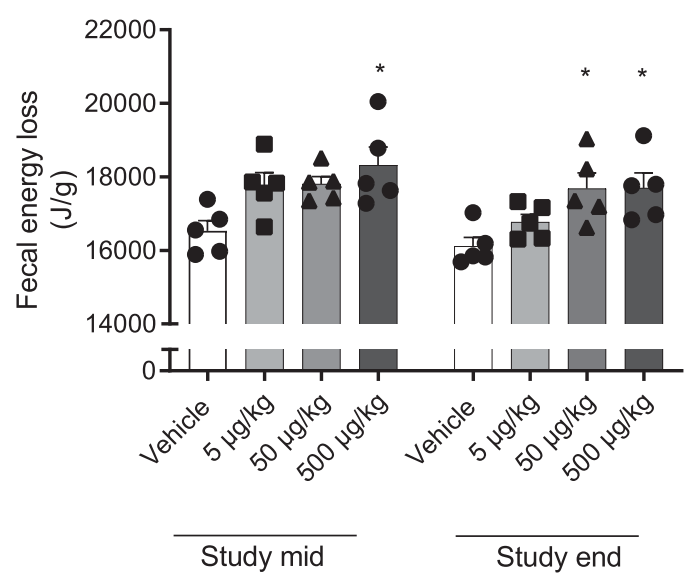

Fig. 5. Fecal energy loss in dose-escalated HFD rats 5 (study mid) and 12 weeks (study end) into the study. $n=5$ /group. Statistical analysis was evaluated with one-way ANOVA followed by Tukey's multiple comparisons test. * compared with vehicle. All data are \pm S.E.M.

with 5 and $500 \mu \mathrm{g} / \mathrm{kg} \mathrm{KBP-066} \mathrm{caused} \mathrm{a} \mathrm{significant} \mathrm{reduction}$ in fasting BG compared with vehicle (Fig. 6 F). Of note, 5 and $500 \mu \mathrm{g} / \mathrm{kg}$ had almost identical fasting BG at study end when normalized to baseline.

Higher Dosing of KBP-066 Preserves Insulin Secretion to a Greater Extent in ZDF Rats. The OGTTs had two purposes: 1) to investigate the dose range effect of KBP066 after short- and long-term treatment and 2) to examine glucose tolerance in the presence (with predosing) or absence (without predosing) of acute transient drug-induced effects. In addition to this, we investigated whether trends observed in the OGTT of the prevention study would translate similarly in an interventive setup without predosing.

After 3 weeks of preventive treatment, initial fasting BG levels differed significantly between vehicle and KBP-066 groups leading to a proportionate improved glucose tolerance (Fig. 7A), although not by iAUC (Fig. 7C). However, the insulin levels required to manage the glucose challenge were significantly lower in all KBP-066 groups, even by iAUC (Fig. 7, E and $\mathrm{G}$ ).

After 8 weeks of preventive treatment, all KBP-066 groups exhibited significantly lower BG levels throughout the OGTT compared with vehicle (Fig. 7B), although the difference was again driven by different baseline BG illustrated by similar iAUCs (Fig. 7D). In contrast to the previous OGTT, both vehicle and KBP-066 groups had flatlined insulin responses of which only 50 and $500 \mu \mathrm{g} / \mathrm{kg}$ produced significantly more insulin than vehicle (Fig. $7 \mathrm{~F}$ ). In line with this, intervention therapy with 5 and $500 \mu \mathrm{g} / \mathrm{kg} \mathrm{KBP}-066$ significantly improved oral glucose tolerance (Fig. 8, A and C), albeit only $500 \mu \mathrm{g} / \mathrm{kg}$ significantly preserved insulin secretion (Fig. 8, B and D).

\section{Discussion}

The objective of this study was to determine the maximally effective dose of the DACRA, KBP-066, by investigating a dose range of 5,50 , and $500 \mu \mathrm{g} / \mathrm{kg}$. We used two different models to shed light on this: 1) an HFD rat model in an acute and a chronic setup focusing on the weight-reducing effect of KBP066 and 2) a diabetic rat model in a preventive and interventive setup to investigate the glucose homeostatic effect of KBP-066. Here we show that there is no additional weight loss 
A

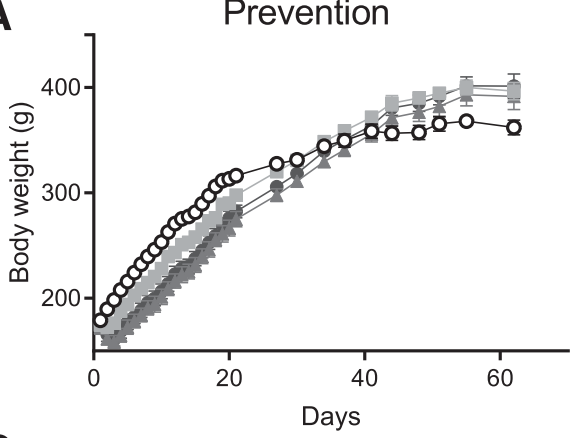

C

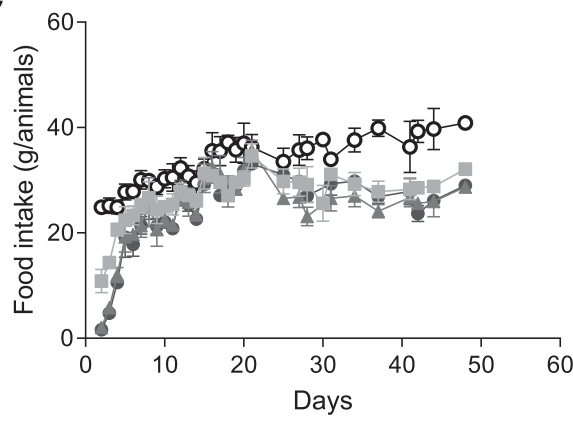

-o- Vehicle

E

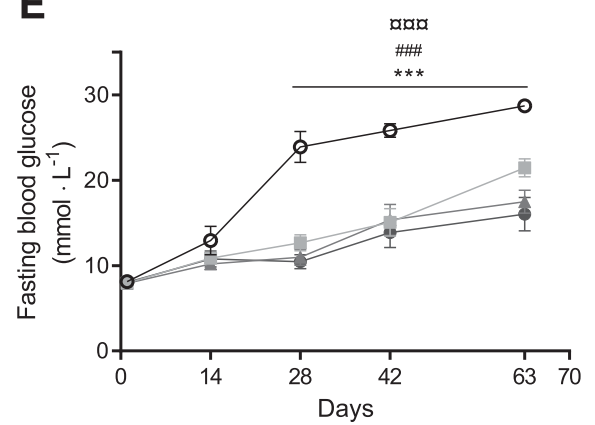

G

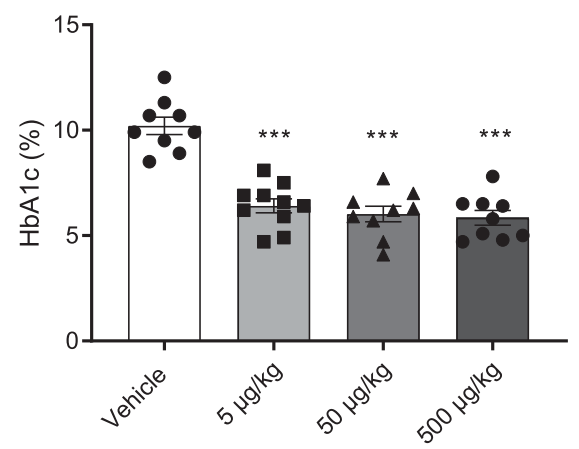

B

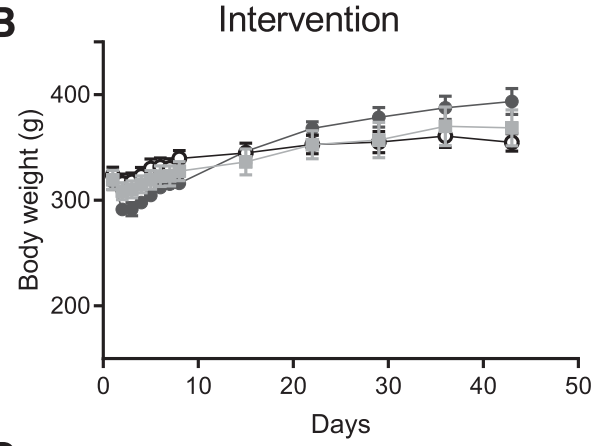

D

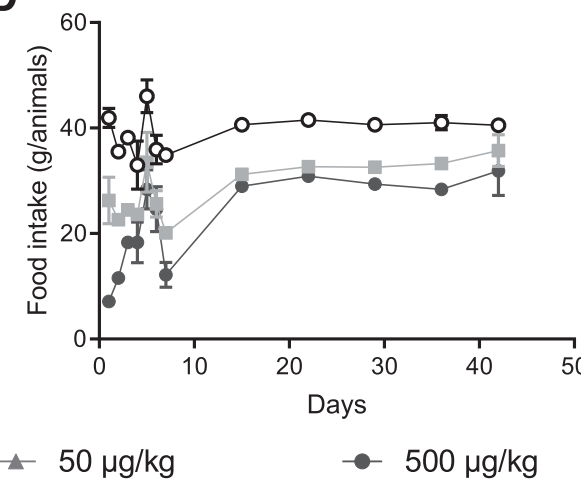

$\mathbf{F}$

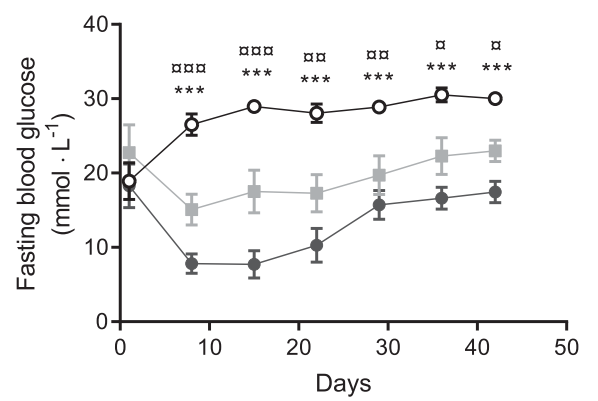

H

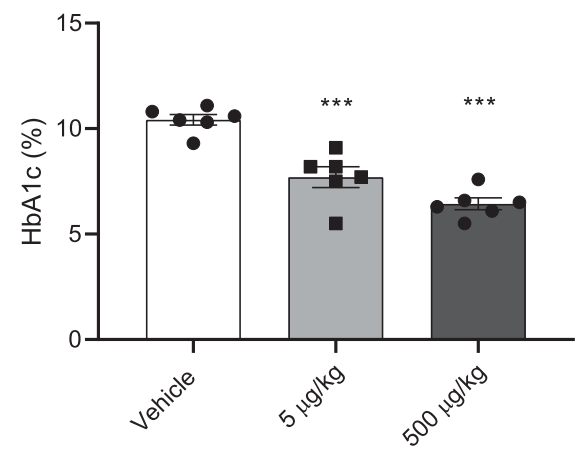

Fig. 6. Prevention and intervention studies in KBP-066-treated ZDF ( $f a / f a)$ rats. Body weight in prevention (A) and intervention study (B). Food intake in prevention (C) and intervention (D) study. Fasting blood glucose in prevention (E) and intervention (F) study. HbA1c in prevention (G) and intervention (H) study. $n=9$ to $10 /$ group, $n=3$ to 4 for food intake. $n=6$ /group in the intervention study, except food intake where $n=$ 2. Statistical analysis was evaluated with two-way ANOVA with repeated measures followed by Tukey's multiple comparison test (E), mixed-effects model followed by Tukey's multiple comparison test (F), and one-way ANOVA with Tukey's multiple comparison test ( $\mathrm{G}$ and $\mathrm{H})$. $\mathrm{E}$ and $\mathrm{F}$ ) a 5 $\mu \mathrm{g} / \mathrm{kg}$ vs. vehicle, ${ }^{\#} 50 \mu \mathrm{g} / \mathrm{kg}$ vs. vehicle, $*$ $500 \mu \mathrm{g} / \mathrm{kg}$ vs. vehicle. G and $\mathrm{H}) *$ compared with vehicle. All data are \pm S.E.M. fa / fa, fatty/fatty; ns, not significant. with increasing doses of the DACRA, KBP-066, demonstrating that maximum weight loss is achieved at $5 \mu \mathrm{g} / \mathrm{kg}$, while higher doses of KBP-066 may preserve insulin secretion to a greater extent.

Preclinical studies with amylin typically use doses in the range of $1-50 \mu \mathrm{g} / \mathrm{kg}$ (dosed i.p. or subcutaneous) to investigate the pharmacological effects (Lutz et al., 1995, 1998; Reidelberger et al., 2004; Isaksson et al., 2005; Wielinga et al., 2007; Potes and Lutz, 2010; Turek et al., 2010; Duffy et al., 2018;
Kalafateli et al., 2018), although use of 50-300 $\mu \mathrm{g} / \mathrm{kg}$ amylin (Roth et al., 2006, 2008; Mack et al., 2007, 2011) and even up to $1000 \mu \mathrm{g} / \mathrm{kg}$ has also been reported (Larsen et al., 2019). Amylin therapy demonstrates a dose-response in terms of body weight loss (Mack et al., 2007; Trevaskis et al., 2008) that seems to reach a plateau around $100-300 \mu \mathrm{g} / \mathrm{kg}$ in which an approximately $8 \%-10 \%$ vehicle-corrected weight loss is achieved (Roth et al., 2006, 2008; Larsen et al., 2019). Although these data are interesting in relation to the optimal dose of DACRA therapy, 
A

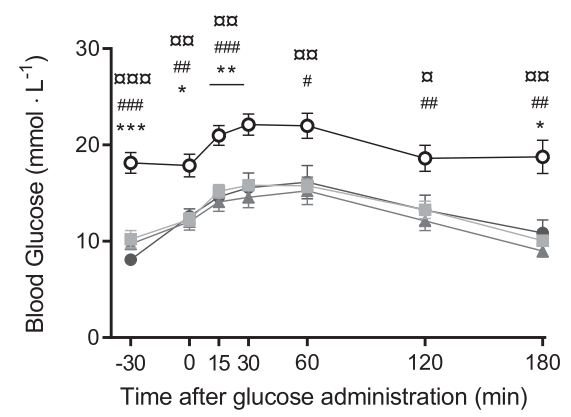

- Vehicle $5 \mu \mathrm{g} / \mathrm{kg}$

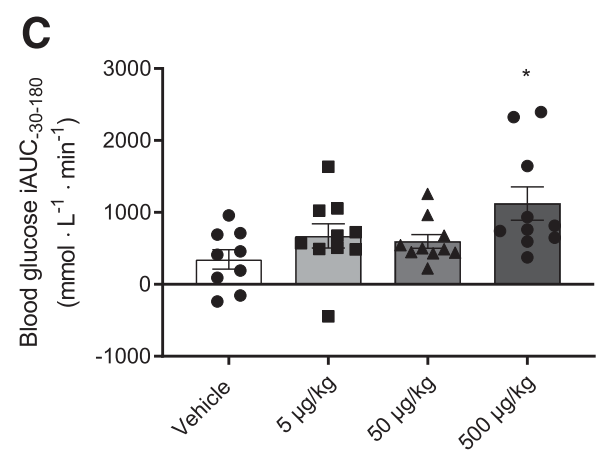

E

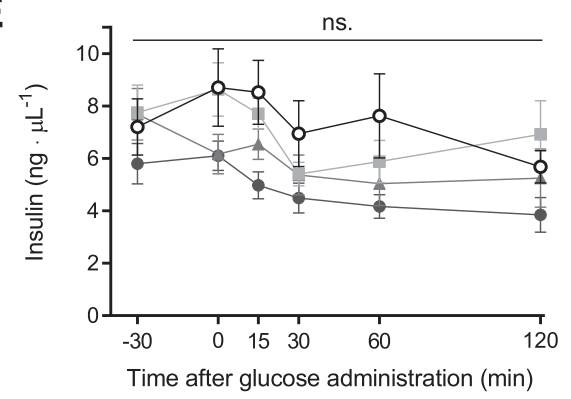

G

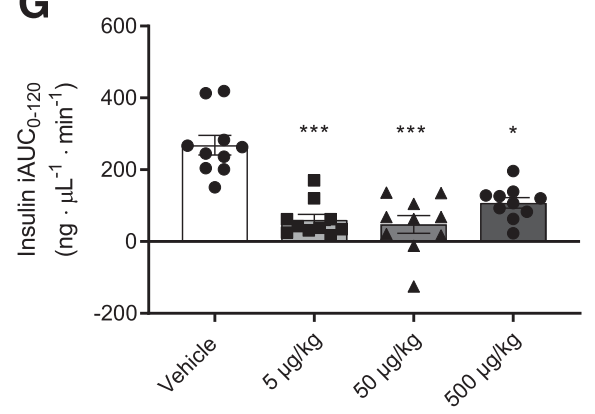

B

\section{8w OGTT}

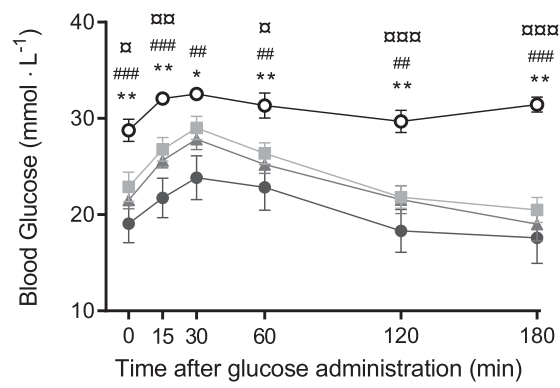

$\neg 50 \mu \mathrm{g} / \mathrm{kg} \longrightarrow 500 \mu \mathrm{g} / \mathrm{kg}$

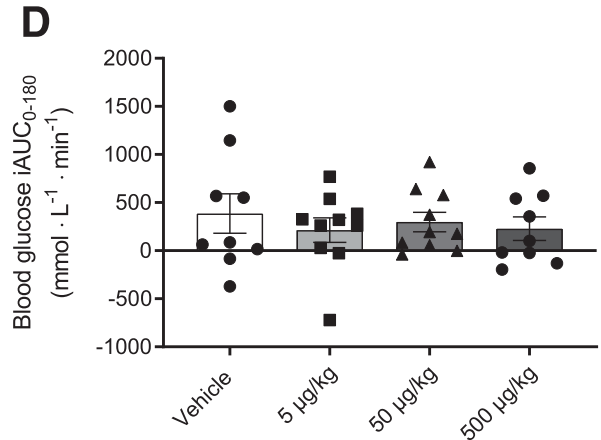

$\mathbf{F}$

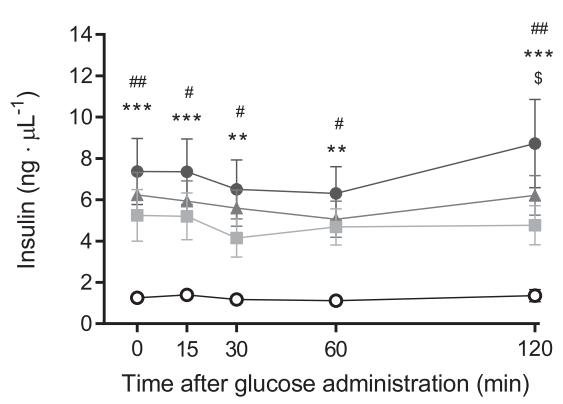

H

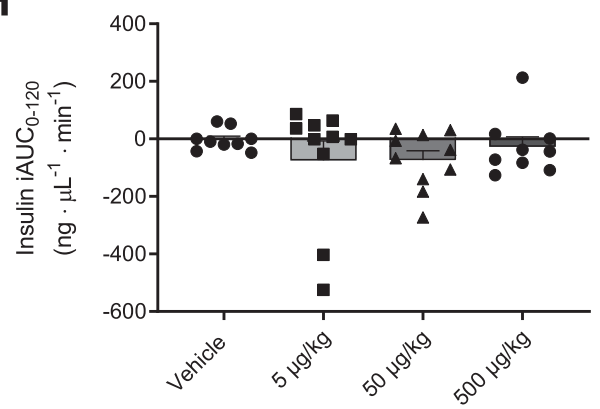

Fig. 7. OGTTs of prevention study in KBP-066-treated ZDF (falfa) rats. Blood glucose (A) and tAUC (C) of blood glucose during predosed OGTT performed after 3 weeks' treatment. Blood glucose (B) and tAUC (D) of blood glucose during OGTT without predosing performed after 8 weeks of treatment. Insulin (E) and iAUC (G) of insulin during predosed OGTT performed after 3 weeks treatment. Insulin $(\mathrm{F})$ and iAUC $(\mathrm{H})$ of insulin during OGTT without predosing performed after 8 weeks' treatment. $n=9$ to 10 /group. Predosing is performed at $t=-30$ minutes and glucose is administered at $t=0$ minutes. Statistical analysis was evaluated with two-way ANOVA with repeated measures followed by Tukey's multiple comparison test (A, B, $\mathrm{E}$, and $\mathrm{F}$ ), or one-way ANOVA with Kruskal-Wallis test (C, D, G, and $\mathrm{H})$. C and $\mathrm{D}) *$ compared with vehicle. $\mathrm{E}$ and $\mathrm{F}$ ) $\mathrm{a}$ $5 \mu \mathrm{g} / \mathrm{kg}$ vs. vehicle, ${ }^{\#} 50 \mu \mathrm{g} / \mathrm{kg}$ vs. vehicle, ${ }^{*}$ $500 \mu \mathrm{g} / \mathrm{kg}$ vs. vehicle, $\$ 5 \mu \mathrm{g} / \mathrm{kg}$ vs. 500 $\mu \mathrm{g} / \mathrm{kg}$. All data are \pm S.E.M. W, weeks (of treatment); ZDF, Zucker Diabetic fatty. a direct comparison is difficult because DACRAs are much more potent than amylin (Wielinga et al., 2007; Braegger et al., 2014; Larsen et al., 2019). Davalintide, which is a dual agonist like KBP-066 (Gydesen et al., 2016), is also more potent than amylin in terms of weight loss (Mack et al., 2010, 2011). In a doseresponse study, the weight-reducing effect of davalintide reached a plateau at approximately 10-100 $\mu \mathrm{g} / \mathrm{kg}$ (Mack et al., 2010). A head-to-head study with KBP-088 and davalintide demonstrated that KBP-088 was more potent than davalintide in terms of both weight loss and glucose control (Gydesen et al., 2016).

Conclusively, our broad dose range study with KBP-066 demonstrates that the maximum weight-reducing effect is obtained already at low doses; $5 \mu \mathrm{g} / \mathrm{kg}$, which is similar to the standard dose used in other DACRA studies (Gydesen et al., 2016, 2017b; Hjuler et al., 2016).

We hypothesized that a progressive dose-escalation regimen may unravel effects previously hidden by tolerability in the small-step dose-escalation setup previously applied (Gydesen et al., 2017a). Despite a transient suppression of food intake at each dose-escalation step, this did not translate to greater weight loss. Amylin therapy alone and combination therapy with amylin and leptin counteract the metabolic suppression that is normally accompanied with reduced food intake (Roth et al., 2006; Wielinga et al., 2007; Seth et al., 2011). Perhaps this 
A

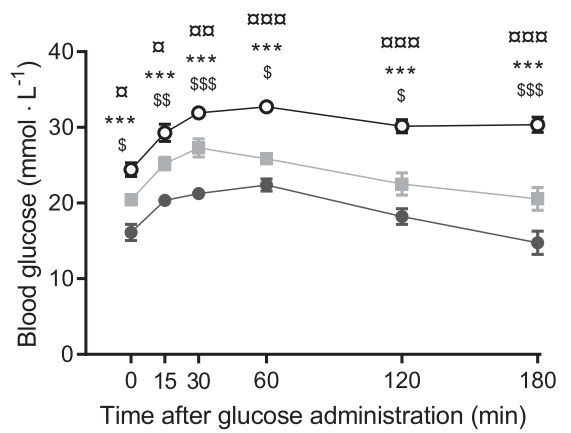

- Vehicle

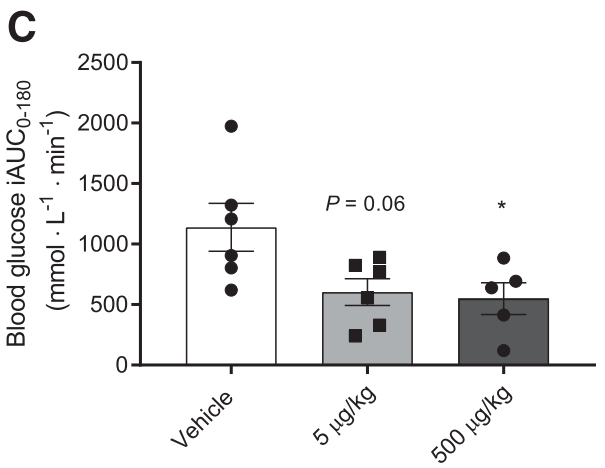

B

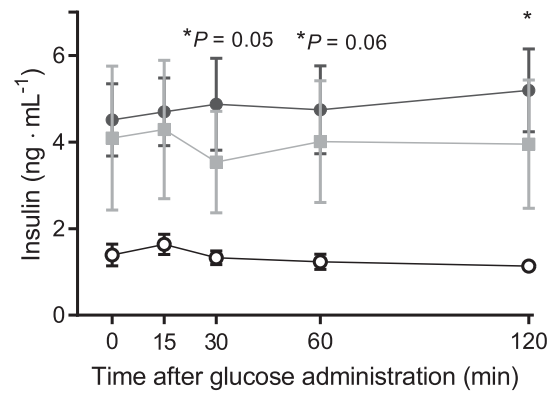

$5 \mu \mathrm{g} / \mathrm{kg}$

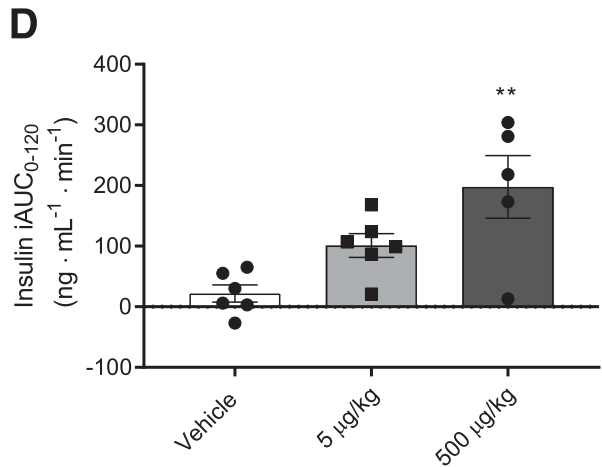

Fig. 8. OGTT of intervention study in KBP-066-treated ZDF (fa/fa) rats. (A) Blood glucose levels and (B) insulin levels during OGTT at study end without predosing. iAUCs of blood glucose (C) and insulin (D) levels during the OGTT. $n=5$ to 6/group. Statistical analysis was evaluated with two-way ANOVA with repeated measures followed by Tukey's multiple comparison test (A and $\mathrm{B}$ ) or one-way ANOVA with Tukey's multiple comparison test (C and D). A and B) a 5 $\mu \mathrm{g} / \mathrm{kg}$ vs. vehicle, ${ }^{*} 500 \mu \mathrm{g} / \mathrm{kg}$ vs. vehicle, ${ }^{\$}$ $5 \mu \mathrm{g} / \mathrm{kg}$ vs. $500 \mu \mathrm{g} / \mathrm{kg}$. C and D) * compared with vehicle. All data are \pm S.E.M. countermechanism is abolished in high-dosed HFD rats, which may explain the absent separation in weight loss despite a suppression in food intake. Alternatively, receptor density may vary in target tissues. The area postrema, a small structure in the brain involved in amylin- and DACRAmediated food intake suppression (Lutz et al., 1998, 2001; Mack et al., 2010; Potes et al., 2010; Braegger et al., 2014) may have a different response and threshold than other tissues, assuming that such tissues are responsible for regulating energy homeostasis.

DACRAs and amylin have been shown to be diabetogenic in acute studies in humans (Petralito et al., 1979; Gattereau et al., 1980; Passariello et al., 1981) and rats and is linked to plasma lactate (Young et al., 1991, 1995; Gydesen et al., 2016; Hjuler et al., 2016). The diabetogenic effect is however transient and is no longer evident with continuous dosing (Giustina et al., 1985; Gydesen et al., 2016; Hjuler et al., 2016). It was therefore noticeable, that 50 and $500 \mu \mathrm{g} / \mathrm{kg} \mathrm{KBP}-066$ caused an acute and transient increase in fasting BG in response to redosing, even after 3 weeks of chronic treatment (Fig. 4A). A similar trend was observed in chronically dosed $\mathrm{ZDF}$ rats (Fig. 7A). Whether this reoccurring but transient increase in BG in response to high dosing has long-term effects is unclear. However, given that high dosing preserved insulin action to a greater extent in $\mathrm{ZDF}$ rats may suggest that it is nonadverse.

DACRAs and pharmacological doses of amylin and amylin analogs are known to reduce plasma insulin without compromising glucose control, suggesting an improved insulin sensitivity (Schmitz et al., 2004; Roth et al., 2006; Hjuler et al., 2016; Gydesen et al., 2017b). However, recent data demonstrates that superhigh dosing with amylin $(1000 \mu \mathrm{g} / \mathrm{kg}$ per day) is less efficient in reducing the insulin required to control a glucose challenge compared with lower amylin doses
(Larsen et al., 2019). Similarly, we observed a trend of inverse dose-response of insulin in HFD-fed rats that was not mediated by predosing or differences in baseline glucose levels. This difference may be driven by body weight and adiposity because there was a small trend of high dosing being less efficient in reducing body weight and adipose tissue.

In $\mathrm{ZDF}$ rats, high dosing preserved insulin secretion to a greater extent, most likely by preservation of $\beta$-cell mass (Feigh et al., 2012) which is also seen with other therapies (Finegood et al., 2001; Sturis et al., 2003). We speculate that the beneficial high dosing in ZDF but not in HFD rats may be due to the genetic background of the $\mathrm{ZDF}$ rats, which includes leptin receptor deficiency and hyperphagia, and a rapid degeneration of $\beta$-cell mass (Topp et al., 2007). Importantly, a functional leptin receptor system seems to be required for a full amylin receptor-mediated response (Duffy et al., 2018). Thus, high-dose treatment with KBP-066 in HFD-fed rats may not translate to high-dose treatment in $\mathrm{ZDF}$ rats due to the blunted amylin receptor-mediated response. This would explain the difference in optimal dosing in the two models.

Pharmacological treatment with DACRAs (Andreassen et al., 2014a; Gydesen et al., 2016, 2017b; Hjuler et al., 2016), and in some studies amylin (Isaksson et al., 2005; Roth et al., 2006; Mack et al., 2007; Osaka et al., 2008), has been suggested to increase energy expenditure. However, the possible role of drug-induced changes in fecal energy loss has not been investigated. The data presented here suggest that fecal energy loss is increased by high-dose treatment ( 50 and $500 \mu \mathrm{g} / \mathrm{kg}$ ). This may explain the difference in weight loss when comparing DACRA rats to pair-fed or pair-weighed rats, albeit the DACRA dose used there was $2.5-5 \mu \mathrm{g} / \mathrm{kg}$, which contradicts the involvement of drug-induced alterations in fecal energy loss as a contributor to the weight loss (Andreassen et al., 2014a; Gydesen et al., 2016, 2017b; 
Hjuler et al., 2016). However, whether fecal energy contributes to the weight loss is still unclear because there was no difference between groups when total caloric intake and total feces output was taken into account.

In conclusion, all three doses $(5,50$, and $500 \mu \mathrm{g} / \mathrm{kg}$ ) of the DACRA KBP-066 was equally efficient in obtaining significant weight loss in an HFD-fed rat model. On the contrary, higher doses (50 and $500 \mu \mathrm{g} / \mathrm{kg}$ ) of KBP-066 preserved insulin secretion in diabetic ZDF ( $f a / f a$ ) rats to a greater extent than the normal dose $(5 \mu \mathrm{g} / \mathrm{kg})$. However, the benefit of high dosing in ZDF rats may be related to the leptin receptor deficiency and consequently may not translate to the clinic.

\section{Acknowledgments}

Special thanks to Tine Rask Licht and Martin Iain Bahl from the National Food Institute at the Technical University of Denmark for providing bomb calorimetry equipment at their laboratory. We would like to acknowledge funding grant from the Danish Research Foundation (Den Danske Forskningsfond).

\section{Authorship Contributions}

Participated in research design: Sonne, Karsdal, Henriksen.

Conducted experiments: Sonne, Larsen, Andreassen.

Performed data analysis: Sonne.

Wrote or contributed to the writing of the manuscript: Sonne, Larsen, Andreassen, Henriksen.

\section{References}

Andreassen KV, Feigh M, Hjuler ST, Gydesen S, Henriksen JE, Beck-Nielsen H, Christiansen C, Karsdal MA, and Henriksen K (2014a) A novel oral dual amylin and calcitonin receptor agonist (KBP-042) exerts antiobesity and antidiabetic effects in rats. Am J Physiol Endocrinol Metab 307:E24-E33.

Andreassen KV, Hjuler ST, Furness SG, Sexton PM, Christopoulos A, Nosjean O, Karsdal MA, and Henriksen K (2014b) Prolonged calcitonin receptor signaling by salmon, but not human calcitonin, reveals ligand bias. PLoS One 9:e92042.

Aronne L, Fujioka K, Aroda V, Chen K, Halseth A, Kesty NC, Burns C, Lush CW, and Weyer C (2007) Progressive reduction in body weight after treatment with the amylin analog pramlintide in obese subjects: a phase 2 , randomized, placebocontrolled, dose-escalation study. J Clin Endocrinol Metab 92:2977-2983.

Bentham J, Di Cesare M, Bilano V, Bixby H, Stevens GA, Riley LM, et al. (2017) Worldwide trends in body-mass index, underweight, overweight, and obesity from 1975 to 2016: a pooled analysis of 2416 population-based measurement studies in 128.9 million children, adolescents, and adults. The Lancet 390 (10113):2627-2642, doi: 10.1016/S0140-6736(17)32129-3 29029897.

Braegger FE, Asarian L, Dahl K, Lutz TA, and Boyle CN (2014) The role of the area postrema in the anorectic effects of amylin and salmon calcitonin: behavioral and neuronal phenotyping. Eur J Neurosci 40:3055-3066.

Chapman I, Parker B, Doran S, Feinle-Bisset C, Wishart J, Strobel S, Wang Y, Burns C, Lush C, Weyer C, et al. (2005) Effect of pramlintide on satiety and food intake in obese subjects and subjects with type 2 diabetes. Diabetologia 48:838-848.

Duffy S, Lutz TA, and Boyle CN (2018) Rodent models of leptin receptor deficiency are less sensitive to amylin. Am J Physiol Regul Integr Comp Physiol 315: R856-R865.

Edelman SV and Weyer C (2002) Unresolved challenges with insulin therapy in type 1 and type 2 diabetes: potential benefit of replacing amylin, a second beta-cell hormone. Diabetes Technol Ther 4:175-189.

Feigh M, Andreassen KV, Neutzsky-Wulff AV, Petersen ST, Hansen C, Bay-Jensen AC, Henriksen JE, Beck-Nielsen H, Christiansen C, Henriksen K, et al. (2012) Oral salmon calcitonin attenuates hyperglycaemia and preserves pancreatic beta-cell area and function in Zucker diabetic fatty rats. Br J Pharmacol 167:151-163.

Finegood DT, Mcarthur MD, Kojwang D, Thomas MJ, Topp BG, Leonard T, and Buckingham RE (2001) Beta-cell mass dynamics in Zucker diabetic fatty rats. Rosiglitazone prevents the rise in net cell death. Diabetes 50:1021-1029.

Fineman M, Weyer C, Maggs DG, Strobel S, and Kolterman OG (2002) The human amylin analog, pramlintide, reduces postprandial hyperglucagonemia in patients with type 2 diabetes mellitus. Horm Metab Res 34:504-508.

Gattereau A, Bielmann P, Durivage J, Davignon J, and Larochelle P (1980) Effect of acute and chronic administration of calcitonin on serum glucose in patients with Paget's disease of bone. J Clin Endocrinol Metab 51:354-357.

Giustina G, Cerudelli B, Cimino A, Rigosa C, Rotondi A, and Radaeli E (1985) Synthetic salmon calcitonin is not diabetogenic in patients with normal or impaired glucose metabolism. J Endocrinol Invest 8:19-23.

Gydesen S, Andreassen KV, Hjuler ST, Christensen JM, Karsdal MA, and Henriksen K (2016) KBP-088, a novel DACRA with prolonged receptor activation, is superior to davalintide in terms of efficacy on body weight. Am J Physiol Endocrinol Metab 310:E821-E827.

Gydesen S, Andreassen KV, Hjuler ST, Hellgren LI, Karsdal MA, and Henriksen K (2017a) Optimization of tolerability and efficacy of the novel dual amylin and calcitonin receptor agonist KBP-089 through dose escalation and combination with a GLP-1 analog. Am J Physiol Endocrinol Metab 313:E598-E607.
Gydesen S, Hjuler ST, Freving Z, Andreassen KV, Sonne N, Hellgren LI, Karsdal MA, and Henriksen K (2017b) A novel dual amylin and calcitonin receptor agonist, KBP-089, induces weight loss through a reduction in fat, but not lean mass, while improving food preference. Br J Pharmacol 174:591-602.

Hjuler ST, Gydesen S, Andreassen KV, Karsdal MA, and Henriksen K (2017) The dual amylin- and calcitonin-receptor agonist KBP-042 works as adjunct to metformin on fasting hyperglycemia and $\mathrm{HbA1c}$ in a rat model of type 2 diabetes. $J$ Pharmacol Exp Ther 362:24-30.

Hjuler ST, Gydesen S, Andreassen KV, Pedersen SLK, Hellgren LI, Karsdal MA, and Henriksen K (2016) The dual amylin- and calcitonin-receptor agonist KBP-042 increases insulin sensitivity and induces weight loss in rats with obesity. Obesity (Silver Spring) 24:1712-1722

Hollander P, Maggs DG, Ruggles JA, Fineman M, Shen L, Kolterman OG, and Weyer C (2004) Effect of pramlintide on weight in overweight and obese insulin-treated type 2 diabetes patients. Obes Res 12:661-668.

Hollander PA, Levy P, Fineman MS, Maggs DG, Shen LZ, Strobel SA, Weyer C, and Kolterman OG (2003) Pramlintide as an adjunct to insulin therapy improves long-term glycemic and weight control in patients with type 2 diabetes: a 1-year randomized controlled trial. Diabetes Care 26:784-790.

Isaksson B, Wang F, Permert J, Olsson M, Fruin B, Herrington MK, Enochsson L, Erlanson-Albertsson C, and Arnelo U (2005) Chronically administered islet amyloid polypeptide in rats serves as an adiposity inhibitor and regulates energy homeostasis. Pancreatology 5:29-36.

Kalafateli AL, Vallöf D, and Jerlhag E (2018) Activation of amylin receptors attenuates alcohol-mediated behaviours in rodents. Addict Biol 24:388-402.

Kolterman OG, Gottlieb A, Moyses C, and Colburn W (1995) Reduction of postprandial hyperglycemia in subjects with IDDM by intravenous infusion of AC137, a human amylin analogue. Diabetes Care 18:1179-1182

Larsen AT, Sonne N, Andreassen KV, Gehring K, Karsdal MA, and Henriksen K (2019) The dual amylin and calcitonin receptor agonist KBP-088 induces weight loss and improves insulin sensitivity superior to chronic amylin therapy. J Pharmacol Exp Ther 370:35-43.

Lutz TA (2005) Pancreatic amylin as a centrally acting satiating hormone. Curr Drug Targets 6:181-189.

Lutz TA, Geary N, Szabady MM, Del Prete E, and Scharrer E (1995) Amylin decreases meal size in rats. Physiol Behav 58:1197-1202.

Lutz TA, Mollet A, Rushing PA, Riediger T, and Scharrer E (2001) The anorectic effect of a chronic peripheral infusion of amylin is abolished in area postrema/ nucleus of the solitary tract (AP/NTS) lesioned rats. Int J Obes Relat Metab Disord 25:1005-1011.

Lutz TA, Senn M, Althaus J, Del Prete E, Ehrensperger F, and Scharrer E (1998) Lesion of the area postrema/nucleus of the solitary tract (AP/NTS) attenuates the anorectic effects of amylin and calcitonin gene-related peptide (CGRP) in rats. Peptides 19:309-317.

Mack C, Wilson J, Athanacio J, Reynolds J, Laugero K, Guss S, Vu C, Roth J, and Parkes D (2007) Pharmacological actions of the peptide hormone amylin in the long-term regulation of food intake, food preference, and body weight. Am J Physiol Regul Integr Comp Physiol 293:R1855-R1863.

Mack CM, Smith PA, Athanacio JR, Xu K, Wilson JK, Reynolds JM, Jodka CM, Lu MG, and Parkes DG (2011) Glucoregulatory effects and prolonged duration of action of davalintide: a novel amylinomimetic peptide. Diabetes Obes Metab 13: 1105-1113.

Mack CM, Soares CJ, Wilson JK, Athanacio JR, Turek VF, Trevaskis JL, Roth JD Smith PA, Gedulin B, Jodka CM, et al. (2010) Davalintide (AC2307), a novel amylin-mimetic peptide: enhanced pharmacological properties over native amylin to reduce food intake and body weight. Int $J$ Obes 34:385-395.

Osaka T, Tsukamoto A, Koyama Y, and Inoue S (2008) Central and peripheral administration of amylin induces energy expenditure in anesthetized rats. Peptides 29:1028-1035.

Passariello N, Giugliano D, Sgambato S, Torella R, and D'Onofrio F (1981) Calcitonin, a diabetogenic hormone? J Clin Endocrinol Metab 53:318-323.

Petralito A, Lunetta M, Liuzzo A, Fiore CE, and Heynen G (1979) Effects of salmon calcitonin on blood glucose and insulin levels under basal conditions and after intravenous glucose load. $J$ Endocrinol Invest 2:209-211.

Potes CS and Lutz TA (2010) Brainstem mechanisms of amylin-induced anorexia. Physiol Behav 100:511-518.

Potes CS, Riediger T, and Lutz TA (2010) Amylin induces ERK 1/2 phosphorylation in structures of the AP/NTS-LPB-Ce-BSTL axis. Appetite 54:670.

Ratner RE, Want LL, Fineman MS, Velte MJ, Ruggles JA, Gottlieb A, Weyer C, and Kolterman OG (2002) Adjunctive therapy with the amylin analogue pramlintide leads to a combined improvement in glycemic and weight control in insulintreated subjects with type 2 diabetes. Diabetes Technol Ther 4:51-61.

Reidelberger RD, Haver AC, Arnelo U, Smith DD, Schaffert CS, and Permert J (2004) Amylin receptor blockade stimulates food intake in rats. Am J Physiol Regul Integr Comp Physiol 287:R568-R574.

Roth JD, Hughes H, Kendall E, Baron AD, and Anderson CM (2006) Antiobesity effects of the $\beta$-cell hormone amylin in diet-induced obese rats: effects on food intake, body weight, composition, energy expenditure, and gene expression. Endocrinology 147:5855-5864.

Roth JD, Trevaskis JL, Wilson J, Lei C, Athanacio J, Mack C, Kesty NC, Coffey T, Weyer C, and Parkes DG (2008) Antiobesity effects of the beta-cell hormone amylin in combination with phentermine or sibutramine in diet-induced obese rats. Int $J$ Obes 32:1201-1210.

Schmitz O, Brock B, and Rungby J (2004) Amylin agonists: a novel approach in the treatment of diabetes. Diabetes 53 (Suppl 3):S233-S238.

Seth R, Knight WD, and Overton JM (2011) Combined amylin-leptin treatment lowers blood pressure and adiposity in lean and obese rats. Int $J$ Obes $\mathbf{3 5}$ : 1183-1192.

Sturis J, Gotfredsen CF, Rømer J, Rolin B, Ribel U, Brand CL, Wilken M, Wassermann K, Deacon CF, Carr RD, et al. (2003) GLP-1 derivative liraglutide in rats 
with beta-cell deficiencies: influence of metabolic state on beta-cell mass dynamics. Br J Pharmacol 140:123-132.

Topp BG, Atkinson LL, and Finegood DT (2007) Dynamics of insulin sensitivity, -cell function, and -cell mass during the development of diabetes in fa/fa rats. Am $J$ Physiol Endocrinol Metab 293:E1730-E1735.

Trevaskis JL, Coffey T, Cole R, Lei C, Wittmer C, Walsh B, Weyer C, Koda J, Baron $\mathrm{AD}$, Parkes DG, et al. (2008) Amylin-mediated restoration of leptin responsiveness in diet-induced obesity: magnitude and mechanisms. Endocrinology 149: 5679-5687.

Turek VF, Trevaskis JL, Levin BE, Dunn-Meynell AA, Irani B, Gu G, Wittmer C, Griffin PS, Vu C, Parkes DG, et al. (2010) Mechanisms of amylin/leptin synergy in rodent models. Endocrinology 151:143-152.

Wielinga PY, Alder B, and Lutz TA (2007) The acute effect of amylin and salmon calcitonin on energy expenditure. Physiol Behav 91:212-217.

Young AA, Wang MW, and Cooper GJS (1991) Amylin injection causes elevated plasma lactate and glucose in the rat. FEBS Lett 291:101-104.
Young AA, Wang M-W, Gedulin B, Rink TJ, Pittner R, and Beaumont K (1995) Diabetogenic effects of salmon calcitonin are attributable to amylin-like activity. Metabolism 44:1581-1589.

Younossi ZM, Koenig AB, Abdelatif D, Fazel Y, Henry L, and Wymer M (2016) Global epidemiology of nonalcoholic fatty liver disease-Meta-analytic assessment of prevalence, incidence, and outcomes. Hepatology 64:73-84.

Zhang L, Bahl MI, Roager HM, Fonvig CE, Hellgren LI, Frandsen HL, Pedersen O, Holm JC, Hansen T, and Licht TR (2017) Environmental spread of microbes impacts the development of metabolic phenotypes in mice transplanted with microbial communities from humans. ISME $J$ 11:676-690.

Zheng Y, Ley SH, and Hu FB (2018) Global aetiology and epidemiology of type 2 diabetes mellitus and its complications. Nat Rev Endocrinol 14:88-98.

Address correspondence to: Nina Sonne, Nordic Bioscience, Herlev Hovedgade 207, 2730 Herlev, Denmark. E-mail: nis@nordicbio.com 